\title{
DAKWAH ISLAMIYAH DAN PROSELYTISME; TELAAH ATAS ETIKA DAKWAH DALAM KEMAJEMUKAN
}

\author{
Yahya \\ Dosen Manajemen Dakwah IAIN Salatiga \\ yahyaslamet54@yahoo.co.id
}

\begin{abstract}
This article focuses on proselytism which convert from one's point of view to other point of view in religion contact, that covers two things; an attempt to convert person from religion to other and convert person from one sect to other. In modern era, Islam is missionary religion that obligates its worshipers to expand its missions where it has rules, ethics, and glorious habit in preaching the religion. The main duty as preacher, he has to comprehend well his religion teaching with various approaches; normative theological, anthropologic, sociologic, philosophic, historical, cultural, and physiologic approach so that religion understanding will be optimal, consciously do the religion teaching, thus it will awaken and return to its pure potency which is purposed to get the happiness in the world and hereafter.
\end{abstract}

Keywords: Dakwah, Proselytism, Pluralism.

\begin{abstract}
Abstrak
Artikel ini fokus pada proselytisme yang merupakan upaya untuk mengonversi atau memindahkan seseorang dari satu sudut pandang ke sudut pandang lainnya, dalam konteks keagamaan, yang mencakup dua hal yakni upaya untuk mengonversi seseorang dari satu agama ke agama lain, dan mengonversi seseorang dari satu aliran keagamaan ke aliran lainnya baik perubahan keimanan dan kepercayaan atau aliran keagamaan. Di era modern, Islam sebagai agama misi yang mewajibkan pemeluknya untuk menyebarluaskan ajarannya yang telah memiliki aturan main, etika, dan kebiasaan luhur dalam berdakwah. Tugas utama pendakwah harus memahami ajaran agama dengan berbagai macam pendekatan teologis normatif, antropolgis, sosiologis, filosofis, historis, budaya, dan psikologis agar pemahaman agama bisa optimal, mengamalkan ajaran agama secara sadar, sehingga menjadikannya bangkit dan kembali ke potensi fitrinya yang tujuannya adalah bahagia di dunia dan akhirat.
\end{abstract}

Kata Kunci : Dakwah, Proselytisme, Kemajemukan 


\section{Pendahuluan}

Rumah ibadah merupakan sarana keagamaan yang penting bagi pemeluk agama di suatu tempat. Selain berfungsi sebagai simbol keberadaan pemeluk agama, rumah ibadah juga sebagai tempat penyiaran agama dan tempat melakukan ibadah (Sekretariat jendral Departemen agama, 1986: 58). Artinya fungsi rumah ibadah di samping sebagai tempat ibadah diharapkan dapat memberikan dorongan kuat dan terarah bagi jamaahnya, agar kehidupan beragama masyarakat sekitarnya menjadi lebih baik.

Azyumardi Azra mengutip pendapat Sayid Qutub menyatakan bahwa semua agama mengajarkan pemeluknya untuk hidup dalam kedamaian. Bahkan agama muncul guna menyantuni dan menyelamatkan anak manusia, menunjukan jalan-jalan kedamaian dan keselamatan, menghilangkan ketidakpastian dan mendatangkan ketentraman, mengajarkan kasih sayang, menyucikan diri dari perbuatan-perbuatan buruk, tercela atau merusak dan lain sebagainya dari perbuatan yang baik (Azra, 1996: 182)

Agama pada dasarnya mempunyai faktor integrasi dan disintegrasi (Basyuni, 2006:5). Untuk memperkuat faktor integrasi sekaligus memperlemah faktor disintegrasi, pada masa orde baru pemerintah mencanangkan tri kerukunan umat beragama meskipun kebijakan ini bersifat top down. Pemerintah juga melalui mekanisme yang demokratis membuat kebijakan-kebijakan yang mengatur tata cara penyebaran agama, pendirian rumah ibadah dan lain sebagainya guna terciptanya ketertiban yang sarat keterikatan sekaligus terciptanya kedamaian yang sarat kebebasan.

Realitas kemajemukan agama sangat disadari oleh para pemimpin bangsa ini. Mereka memandang bahwa kemajemukan bukanlah halangan untuk mewujudkan persatuan dan kesatuan serta untuk mewujudkan cita-cita nasional dalam wadah Negara Kesatuan Republik Indonesia. 
Bagi mereka kemajemukan adalah bagian dari sunnatullah. Agama mengingatkan bahwa kemajemukan terjadi atas kehendak Tuhan Yang Maha Esa, sehingga harus diterima dengan lapang dada dan dihargai, termasuk di dalamnya perbedaan keyakinan keagamaan.

Kehadiran SKB tentang tata cara pendirian rumah ibadah (SKB No. 1 Tahun 1969 yang akhirnya diperbaharui dengan SKB Menteri Dalam Negeri dan Menteri Agama RI No 8 TAHUN 2006 dan No 9 Tahun 2006, juga SK Menteri Agama tentang Penyiaran Agama (SK Menag No. 70 tahun 1978), aplikasi UU Pendidikan Nasional yang mewajibkan anak didik menerima pelajaran agama sesuai yang dianutnya (UU No.2 tahun 1989) membawa angin segar terciptanya keharmonisan kerukunan umat beragama. Namun fakta di lapangan menunjukan ketidakefektifan peratuan bersama tersebut.

Efektifitas dan bekerjanya sebuah peraturan memang sangat tergantung pada berbagai macam faktor baik ditinjau dari sisi substansi, sruktur dan kultur peraturan tersebut (Soerjono, 1993:5)

Dalam lintasan sejarah kerukunan umat beragama di Indonesia pernah ada kesepakatan bersama antara para pembesar agama. Kesepakatan itu berupa pembatasan dakwah, bahwa dakwah atau mengajak untuk memeluk agama itu hanya diperbolehkan pada obyek yang belum memeluk agama. Mayoritas yang hadir dalam musyawarah tersebut menyetujui kesepakatan tersebut. Akan tetapi ada yang satu pihak yang tidak menyetujuinya. Yaitu Kristen. Sebenarnya dalam internal agamaagama di Indonesia sudah ada kesadaran terhadap dampak negatif dari pelanggaran terhadap peraturan bersama tersebut. Kesadaran itu memandang perlu adanya paradigma baru dalam dakwah atau misi. Pendeta Victor I Tanja melihat perlunya paradigma baru dalam misi atau dakwah dalam situasi Indonesia seperti ini yang berorientasi bukan pada penambahan jumlah dalam artian kuantitatif, namun tujuan misi adalah menciptakan umat beragama yang tinggi ilmu, iman dan pengabdian 
(Andito,ed,1999:73). Hal ini dikuatkan lagi oleh Romo YB Mangunwijaya yang lebih mementingkan iman dalam beragama karena iman bersifat inklusif (Andito,ed, 1999:387).

Kenyataan di lapangan menunjukan sesuatu yang berbeda. Fakta menunjukan bahwa berdakwah untuk memeluk suatu agama tetap saja kadang tidak mengindahkan etika, bahkan ada yang secara teroganisir rapi memprogamkan berbagai macam program dalam berbagai bidang yang endingnya adalah dakwah atau misi. Media Dakwah pernah menyajikan informasi akurat tantang program-program tersebut di atas hasil penyaduran dari majalah Crescent International terbitan Toronto Canada. Program tersebut mencakup usaha pengurangan jumlah umat Islam di Indonesia dengan berbagai macam strateginya dan rencana kristenisasi dalam berbagai bidang dari ekonomi, pendidikan, politik, informasi, pembangunan, hukum dan undang-undang sampai keputusan masalah internal dalam pemerintahan (Media Dakwah, Juni 1990)

Dampak dari tidak mengindahkan aturan main yang disepakati bersama adalah terjadinya proselytisme. Proselytisme terjadi karena dalam berdakwah tidak mengindahkan etika universall (Baidhawi, 2005:117). Motivasi pindah agama oleh sebagian masyarakat ke kristen di Salatiga pasca 1965 seperti yang pernah diteliti oleh Singgih memang beragam, diantaranya adalah alasan politik, penggunaan bahasa ibu dalam ajaran kristen dan ajaran kristen tidak terlalu rumit serta tidak banyak memberi sanksi (Singgih, 2008:176). Tentu motivasi tersebut akhir-akhir ini bisa sangat berbeda.

Fenomena tersebut tentu mengundang reaksi dari berbagai macam kalangan, baik para pemuka agama-agama, akademisi dan intelektual maupun pemerintah. Masyarakat muslim khusunya memandang perlu untuk melakukan aksi konkrit yang bukan saja ikut berperan aktif dalam menciptakan dan menjaga kerukunan umat beragama, juga memberi peringatan kepada masyarakat muslim akan bahaya proselytisme sekaligus 
memahamkan masyarakat akan pentingnya berdakwah secara prosedural melalui lembaga-lembaga pendidikan, majlis taklim dan masjid dan sarana dakwah lainnya.

Agaknya masjid yang merupakan sentral dakwah Islam dan pada masa silam mampu berperan sedemikian luas karena faktor-faktor antara lain; keadaan masyarakat yang masih sangat berpegang teguh kepada nilai, norma, dan jiwa agama, kemampuan pembina-pembina masjid menghubungkan kondisi sosial dan kebutuhan masyarakat dengan uraian dan kegiatan masjid dan manifestasi pemerintahan terlaksana di dalam masjid baik pada pribadi-pribadi pemimpin pemeritah yang menjadi imam atau khatib maupun dalam renungan-renungan masjid yang dijadikan tempat kegiatan pemerintahan dan syura (Shihab, 1996:462463) sekarang ini tidak sedemikian rupa.

Di sisi lain dakwah yang merupakan satu bagian yang pasti ada dalam kehidupan umat beragama dan dalam ajaran agama Islam ia merupakan suatu kewajiban yang dibebankan oleh agama kepada pemeluknya kadang pelaksanaannya sering kali tidak menemukan sasarannya, materi tidak membumi atau menyentuh problem-problem dasar mereka sebagai kelemahan sehingga kelemahan dalam ekonomi digunakan sementara pihak untuk maksud tertentu.(Shihab, 1994:398) meski Islam memberi belasan solusi untuk keluar dari kemiskinan (Budiharjo, 2007:193)

\section{Konsep Dakwah Islamiyah di Era Kemajemukan}

Istilah proselytisme dalam bahasa Inggris berasal dari bahasa Yunani, yakni prefiks 'pros' (menuju) dan kata kerja 'erchomai' (datang). Kata ini terambil dari proselytize yang berarti menarik masuk.

Istilah ini pada umumnya menjelaskan upaya-upaya untuk mengonversi atau memindahkan seseorang dari satu sudut pandang ke sudut pandang lainnya. Biasanya istilah ini digunakan dalam konteks keagamaan. Berarti proselytisme mencakup dua hal dalam bidang keagama- 
an, yakni upaya-upaya untuk mengonversi seseorang dari satu agama ke agama lain, dan mengonversi seseorang dari satu aliran keagamaan ke aliran lainnya. Yang pertama menyangkut perubahan keimanan atau faith, religion dan kepercayaan atau belief, sedangkan yang terakhir terkait dengan perubahan paham/aliran keagamaan (Zakiyudin, 2005:113). Dan ruh proselitysme ini muncul karena kaum Nasrani berpegang teguh kepada teologi yang "eksklusif" dan "nonkompromistis".(Husaini, 2002:13)

Semangat proselytisme sebenarnya adalah kebebasan dalam arti yang luas yang keluar dari frame kebebasan itu sendiri. Dalam kebebasan ada dua hal yang tak terpisahkan, yaitu hak dan kewajiban. Dalam konteks dakwah atau misi berarti bahwa penganut sebuah agama mempunyai hak untuk mendakwahkan agamanya kepada siapa saja tanpa melupakan sisi kewajiban untuk menghormati keyakinan agama orang lain, melakukan dakwah dengan tanpa memaksa, dan juga kebebasan orang lain untuk mendakwahkan keyakinannya. Dalam bahasa sederhana bisa dikatakan bahwa hak seseorang dibatasi oleh hak orang lain. Barangkali kehadiran SKB tentang tata cara pendirian rumah ibadah (SKB No. 1 Tahun 1969 yang akhirnya diperbaharui dengan SKB Menteri Dalam Negeri dan Menteri Agama RI No 8 TAHUN 2006 dan No 9 Tahun 2006), dan SK Menteri Agama tentang Penyiaran Agama (SK Menag No. 70 tahun 1978), aplikasi UU Pendidikan Nasional yang mewajibkan anak didik menerima pelajaran agama sesuai yang dianutnya (UU No.2 tahun 1989) adalah dalam rangka mengatur hak-hak dan kewajiban seluruh penganut agama di Indonesia dalam berdakwah nutuk menuju Indonesia yang tertib dan rukun. Dalam Islam, berdakwah dengan cara-cara yang tidak etis tidak bisa diterima.

Adapun pola berpindahnya sesorang dari suatu agama ke agama lain yang biasanya dikenal dengan istilah konversi agama ada dua model yaitu internal dan aksternal. Konversi internal yaitu pindahnya seseorang dari suatu madzhab ke madzhab lain dalam satu agama. Sedangkan 
eksternal adalah pindahnya seseorang dari agama ke agama lainnya.

Konversi dapat dibedakan menjadi dua macam, yaitu perubahan secara bertahap volitional yaitu konversi yang terjadi secara berproses, sedikit demi sedikit hingga kemudian menjadi seperangkat aspek dan kebiasaan ruhaniah yang baru dan perubahan secara drastis atau self surrender yang terjadi secara mendadak.

Faktor-faktor yang menyebabkan konversi adalah pengaruh sosial yang berwujud hubungan antar pribadi, baik pergaulan yang bersifat keagamaan maupun yang bersifat non agama, kebiasaan yang rutin, anjuran atau propaganda dari orang- orang yang dekat, seperti keluarga, sahabat dan sebagainya, pengaruh pemimpin agama, pengaruh perkumpulan berdasarkan hobi, pengaruh kekuasaan pemimpin.

Usaha untuk mengkonversi pemeluk agama lain ke dalam agama seseorang adalah tidak fair. Dalam sejarah Indonesia, proselytisme terjadi karena dorongan kuat politik etis dan politik asosiasi Belanda. Menurut penjelasan Boland, buku Hendrik Kraemer mengungkapkan dengan jelas bahwa orang-orang Kristen mempunyai rencana untuk mengkristenkan dunia, khususnya Indonesia. Mereka bertujuan menundukkan dunia Islam. Bahkan, Kraemer membandingkan Islam dengan Nazi.

Singkatnya pola-pola tersebut merujuk kepada program-program yang telah dicanangkan di Toronto Canada. Program tersebut mencakup usaha pengurangan jumlah umat Islam di Indonesia dengan berbagai macam strateginya dan rencana kristenisasi dalam berbagai bidang dari ekonomi, pendidikan, politik, informasi, pembangunan, hukum dan undang-undang sampai keputusan masalah internal dalam pemerintahan ( Media Dakwah, Juni 1990)

\section{Dakwah Islamiyah yang Cerdas dan Etis dalam Menghadapi Proselytisme}

Secara etimologis kata dakwah berasal dari bahasa Arab yaitu دعوة yang berarti dasar kecenderungan sesuatu yang disebabkan suara dan 
kata-kata (Warson,1984:58). Dari kata kerja دعا - يدعو ini terbentuk isim mashdar دعاء yang berarti panggilan, seruan, do'a, permohonan, kutukan dan laknat (Ali,1996:895) dan juga terbentuk isim mashdar دعوة yang berarti ajakan, undangan, himbauan, permintaan, misi, propaganda. (Ali,1996: 896).

Kata dakwah menurut arti bahasa mempunyai beberapa arti yaitu mengharap dan berdo'a kepada Allah SWT seperti dalam al-Quran Surat al-Baqarah ayat 186, memanggil dengan suara lantang seperti dalam alQuran Surat al-Rum ayat 25, dan mendorong orang untuk memeluk suatu keyakinan tertentu sepert al-Quran Surat al-Baqarah ayat 22.

Secara terminologis dakwah bisa didefinisikan sebagai ishlah, yaitu memperbaiki keadaan kaum muslimin dan memberi petunjuk kepada orang-orang kafir agar mau memeluk Islam atau proses memindahkan kepada situasi lebih baik. Dia juga merupakan suatu proses penyampaian, ajakan atau seruan kepada orang lain agar mau memeluk, mempelajari dan mengamalkan ajaran agama secara sadar, sehingga menjadikannya bangkit dan kembali ke potensi fitrinya yang tujuannya adalah bahagia di dunia dan akhirat. (Budiharjo, 2007:2). Dakwah adalah mengajak dan menyeru manusia agar mengakui Allah sebagai Tuhan yang berhak untuk disembah dan menjalani kehidupan sesuai dengan ketentuan-ketentuanNya yang ada di dalam al-Quran dan Sunah (Yani, 2005:1)

Al-Qur'an menyebut kalimat dakwah dengan berbagai macam bentuk derivasinya berkali-kali baik dalam bentuk kata kerja maupun kata benda sebanyak 219 kali. Hal tersebut menunjukan perhatian yang sangat besar dari Al-Quran terhadap kebutuhan manusia kepada dakwah agar kehidupan bisa lebih baik dari waktu ke waktu seiring dengan perubahan yang tidak terelakkan dalam segala lini kehidupan. Kalimat dakwah juga bisa disepadankan dengan kalimat tabligh, amar ma'ruf dan nahi munkar, washiyah, nashihah dan khutbah, jihadah, mau'izhah dan mujadalah, dan tadzkirah atau indzar (Syam, 2007:4-6) 


\section{Hakikat Dakwah yang Mencerdaskan dan Beretika}

Pada hakikatnya dakwah berkisar pada masalah-masalah penting yaitu; Pertama, Dakwah sebagai jalan menuju kepada ketauhidan. Tauhid secara etimologis berarti pengesaan dan keimanan atas keesaan Allah (Ali,1996:609). Tauhid adalah penafian dan penetapan; menafikan empat hal dan menetapkan empat hal. Penafian sesemabahan atau alihah, thawaghit, tandingan-tandingan atau andad dan tuhan-tuhan atau arbab dan penetapan maksud dan tujuan, pengagungan dan kecintaan, takut dan harap dan takwa (al Qahthani, 2000:26-28).

Tauhid adalah tema paling sentral dari seluruh ajaran para Nabi dan Rasul. Allah menghendaki umat manusia meyakini keberadaanNya yang Esa dengan segala sifat-Nya yang sempurna agar menjadi satu-satunya fokus penyembahan, pengabdian dan pensucian. Dengan tawhid ini manusia akan terus hidup mulia sebab ia akan terhindar dari penuhanan sesama makhluk yang tak lepas dari segala kekurangan dan cacat. Jadi bertawhid adalah satu-satunya cara untuk mencapai kemuliaan sejati manusia. Di samping itu, jika seluruh umat manusia meyakini dan mengaktualisasikan tawhid akan tercipta kesatuan (unity) kemanusia yang akan melahirkan egalitarianisme. Tauhid adalah mengesakan Allah dalam ibadah. Tauhid merupakan inti dakwah para rosul yang Allah utus untuk mendakwahkan agama-Nya kepada para hamba-Nya (Wahab, 2004:5).

Kedua, dakwah sosial masyarakat. Dakwah sosial masyarakat di sini yang dimaksud adalah ishlah dalam masyarakat yang berarti menjadikan masyarakat itu dapat diperbaiki sehingga mau mengikuti peraturan-peraturan yang ditentukan dalam agama dan tidak berbuat kerusakan, karena kata ishlah berarti perbaikan, restorasi, dan reformasi (Ali,1996:141). Hakekat dakwah semacam sesuai dengan al-Quran Surat al-Anfal ayat 24, al-Quran Surat al-Imran ayat 104, dan al-Quran Surat al-Hajj ayat 77-78. 
Ketiga, dakwah sebagai al- Amru bi al Ma'uf dan al-Nahyu 'an alMunkar. Konsep ma'ruf sebagaimana dapat dipahami dari al-Quran seperti dalam surat Ali Imran ayat 104 dan diperkuat oleh surat Ali Imran ayat 110 dan Hadis tidak hanya mencakup muatan keagamaan dalam pengertian sempit, namun juga meliputi konsep-konsep yang mendasarkan pertimbangan akal atau dengan kata lain akal berperan (al-Marāghi, 1993:34). Ajakan kepada ma'ruf dalam bahasa hukum berkedudukan pada fungsi kedua dari hukum yaitu social engineering dan mencegah kemunkaran adalah sebagai social controll.

Kata ini biasa diartikan sebagai segala sesuatu yang kebaikannya diketahui oleh jiwa manusia dan jiwa ini menyenanginya dan tentram kepadanya. Dia merupakan sesuatu yang baik dalam pandangan umum suatu masyarakat selama hal itu sesuai dengan al-khair yang merupakan nilai universal yang diajarkan al-Qur'an dan sunnah (Shihab, 2000:165)

Sedangkan al-Munkar adalah lawan dari al-Ma'ruf. Dia adalah sesutu yang ditolak atau diingkari oleh akal sehat dan karakter yang baik (al-Maraghi, 1993:34). Dia merupakan perbuatan yang diingkari oleh akal dan syara.

Dalam konteks dakwah, perintah kepada yang $M a$ 'rufmengandung bahwa tidak boleh ada paksakan dalam mendakwahkan nilai-nilai ilahi, tetapi nilai-nilai itu harus disebarluaskan melalui jalan persuasif dalam bentuk ajakan yang baik (Shihab, 2000:165). Tantangan dakwah yang terberat bukan menyeru kepada al-khair atau mengajak kepada al-ma'ruf, namun mencegah manusia dari kemungkaran politik, kemungkaran sosial, kemungkaran ekonomi, kemungkaran kultural, dan bahkan kemungkaran agama (Zakiyudin, 2005:76).

\section{Dakwah adalah Kebutuhan bukan Sekedar Kewajiban}

Dakwah merupakan sebuah kewajiban yang dibebankan kepada setiap muslim baligh sesuai dengan kemampuan masing-masing. Perintah 
untuk berdakwah dijelaskan antara lain dapat kita lihat dalam al-Quran dan Sunnah yang diantaranya bisa kita lihat dalam Q.S. al-Nahl (16):25

Ada beberapa catatan penting dalam memahami ayat 104 dari surat Ali Imron bahwa fi'il mudhori' yang disertai laamul amri adalah menunjukan perintah dan pada dasarnya perintah sesuai dengan kaidah ushuliyah adalah kewajiban. Kedua kata من dalam kalimat منكم dalam ayat tersebut menunjukkan للبيانdan bukan للتبعيضdan itu artinya bahwa kewajiban dakwah tidak menjadi kewajiban atas sebagian diantara umat Islam sehingga status hukumnya adalah fardlu kifayah (at-Thobathoba'i, 1991:427) Kemudian kata أمة yang dimaksud adalah seluruh umat manusia.

Hemat kami, yang paling tepat adalah sebagaimana Ibnu Katisr menjelaskan bahwa hendaknya ada satu golongan yang berusaha untuk urusan itu, meskipun berdakwah adalah kewajiban setiap diri umat seluruhnya (Ibn Katsir :390). Dan yang berkewajiban adalah semua muslim, akan tetapi yang mendapatkan pahala adalah sebagian dari mereka sesuai dengan kata petunjuk dalam ayat tersebut (at-Thobathoba'i, 1991:427)

\section{Berdakwah Secara Sistematis Metodologis}

Allah memberikan tuntunan kepada para da'i agar dalam dakwah yang mereka lakukan hendaknya terorganisir dengan baik dengan menggunakan cara atau metode yang efektif dan efesien sesuai situasi dan kondisi yang ada pada unsur-unsur dakwah. Ada tiga metode sebagaimana Al-Qur'an surat al-Nahl ayat 125 memaparkan yaitu;

\section{Dengan Hikmah}

Hikmah adalah perkataan yang tepat lagi tegas yang dibarengi dengan dalil yang dapat menyingkap kebenaran dan melenyapkan keserupaan (al-Marāghi, 1993:42) atau ungkapan tentang pengetahuan sesuatu yang paling utama melalui ilmu-ilmu yang utama. Hikmah 
adalah ilmu yang benar yang menjadi sifat yang jelas dalam jiwa dan mengendalikan kemauan mengarahkannya kepada perbuatan. Hikmah adalah menyampaikan kebenaran dengan ilmu dan akal (alThobathoba'i,1991:372). Jadi hikmah adalah sesuatu yang paling utama dari segala sesuatu, baik pengetahuan maupun perbuatan. Sesuatu yang bila digunakan atau diperhatikan akan mendatangkan kemaslahatan dan kemudahan yang besar atau lebih besar, serta menghalangi terjadinya madlorot atau kesulitan yang besar atau lebih besar (Shihab, 2000:386)

Dakwah dengan hikmah berarti bahwa seorang da'i sangat berkompeten dalam bidangnya dan mempunyai kemampuan untuk bisa menjadi teladan dengan membuktikan dirinya yang telah memulai berbuat yang saleh sebelum mengajak orang lain untuk berbuat karena sering kali dakwah dengan cara semacam ini biasanya ditujukan kepada ahli pikir dan ahli ilmu yang kritis. Dakwah dengan hikmah juga bisa diartikan dengan berbuat yang tepat dengan cara yang tepat pada waktu yang tepat (Takariawan, 2005:30)

\section{Dengan Mau'idztu al-Hasanah}

Mau'idzah adalah mengingatkan kebaikan dengan cara yang meluluhkan hati (al-Thobathobai, 1991:372) atau uraian yang menyentuh hati yang mengantarkan kepada kebaikan (Shihab, 2000:387). Berdakwah dengan mau'idzah itu bisa dilakukan dengan memberi nasehat dan memberi ingat kepada orang lain dengan bahasa yang baik yang dapat menggugah hatinya sehinngga pendengar dapat menerima nasehat itu dengan baik (Amin, 1997:26). Hal ini bisa dilakukan dengan bentuk menuturkan kisah-kisah keadaan umat yang lalu baik yang positif maupun negatif, dengan memberi kabar gembira dan ancaman,dengan menjelaskan keadaan surga dan neraka beserta keadaan penghuninya dan dengan mengungkapkan perumpamaan-perumpamaan untuk mencari kesamaan-kesamaan.(Amin,1997:28-29). 


\section{Dengan Mujadalah bi al-Lati Hiya Ahsan}

Al-Thobathoba'i tidak menganggap cara ini sebagai dakwah dengan maknanya yang khusus (al-Thobathoba'i, 1991:372). Meskipun demikian dia merupakan diskusi atau bukti-bukti yang mematahkan alasan atau dalil mitra diskusi atau menjadikannya tidak bertahan baik yang dipaparkan itu diterima oleh semua orang maupun hanya oleh mitra bicara (Shihab, 2000:387).

Dakwah dengan cara ini menuntut agar da'i mempunyai kecakapan dalam tukar pikiran, sharing, debat dan diskusi dan lainnya. Yang perlu diperhatikan adalah bahwa yang diajak sharing adalah kawan bukan lawan. Bisanya metode ini tepat bagi golongan menegah yang tidak sampai derajat ahli pikir tapi bukan orang awam.

Dakwah juga bisa dilakukan dengan dakwah bi al-maq $\square l$ (dengan ceramah, tulisan dan semacamnya) dan bi al-h $\square l$ yang disebut juga dakwah pembangunan. Dakwah bil haal merupakan kegiatan-kegiatan dakwah yang diarahkan untuk meningkatkan kesejahteraan dan kebahagiaan hidup umat, baik rohani maupun jasmani yang titik beratnya ada dalam peningkatan kualitas keberagamaan dalam ilmu dan amal, meningkatkan kecerdasan intelektual, sosial, emosional, dan spiritual umat yang mengantarkan mereka hidup sejahtera dunia dan akhirat (Ayub, 1996: 18-19).

\section{Berdakwah yang sarat ororientasi}

Target dakwah adalah mewujudkan sumber daya manusia yang bertakwa kepada Allah SWT dalam arti yang seluas-luasnya. (Yani,2005:1). Dakwah bwrtujuan agar manusia menjadi hamba Allah yang selaras dengan tuntunan-Nya dan mengubah pandangan hidup manusia kepada ranah yang lebih berarti (Najamudin,2008:10). Secara tegas tujuan utama dakwah telah ditetapkan oleh Allah dengan tegas dengan rumusan ilallah atau ilaa rabbika (Takariawan, 2005:3). 
Menurut al-Quran, tujuan akhir kehidupan manusia adalah tercapainya al-falah yang mengandung tiga hal utama yaitu; Pertama, kesinambungan dan kelestarian hidup (al-Baqa). Kelestarian dan kesinambungan hidup manusia di alam semesta ini sangat bergantung pada kemampuannya memanfaatkan semua sumber daya alam dan menjaga kelanggengannya.

Dakwah yang berhasil adalah dakwah yang mampu mengajak manusia untuk menjaga kelestarian dan kesinambungan hidup dirinya sendiri - yakni sehat secara fisik dan bebas dari segala macam penyakit, dan dapat bekerja secara produktif untuk menjamin hidupnya dan mendorong manusia untuk secara sadar melestarikan lingkungan hidup dan menjaga keseimbangan ekologis dan ekosistem, serta menjaga kesehatan lingkungan (Zakiyudin ,2005:84).

Selain itu, al-faläh juga mengandung arti kelayakan hidup (al-Ghina) yang berarti kekayaan dan kecukupan (Ali, 1996:1360). Beberapa ayat alQur'an menyebutkan kata ini dengan maksud kekayaan dan kecukupan dalam hal harta atau rezeki.

Implikasi dari kandungan makna ini adalah bahwa dakwah merupakan upaya menyeru manusia untuk menjadi orang yang mampu dan berkecukupan secara material dan secara mental. Oleh karena itu keberhasilan dakwah dapat dilihat dari seberapa besar dakwah itu dapat memotivasi masyarakat untuk dapat mengurangi kemiskinan dan mampu mengarahkan setiap obyek dakwah untuk bisa hidup mandiri dan mempunyai mental kaya (Zakiyudin ,2005:86).

Islam dalam konteks dakwah semacam ini sebenarnya telah memberikan jalan luas dan beragam guna mengangkat muslimin dari jurang kemiskinan. Tidak kurang dari 12 solusi Islam yang berfungsi sebagai wasilah pengentasan kemiskinan sebagai sarana dakwah seperti pemberian makanan, ihsan, fidyah, ghanimah, warisan, fa'i, kifarat, zakat dan lainnya (Budiharjo, 2007:134-198). 
Kedua, kemuliaan hidup (al-'izz) yang meliputi kekuasaan dan kemuliaan. Dalam konteks dakwah al-izz yang menjadi tujuan dakwah dimaknai dengan usaha untuk membawa manusia agar memiliki harga diri dan kemuliaan hidup. Oleh karena itu, dakwah dapat dikatakan berhasil jika mampu mengondisikan masyarakat untuk mempergunakan kebebasan sipil guna melindungi harkat dan martabat kehidupan dan mendorong mereka untuk terbebas dari segala jeratan hutang (Zakiyudin, 2005:88).

Di sisi lain dakwah yang merupakan satu bagian yang pasti ada dalam kehidupan umat beragama dan dalam ajaran agama Islam ia merupakan suatu kewajiban yang dibebankan oleh agama kepada pemeluknya kadang pelaksanaannya sering kali tidak menemukan sasarannya, materi tidak membumi/menyentuh problem-problem dasar mereka sebagai kelemahan sehingga kelemahan dalam ekonomi digunakan sementara pihak untuk maksud tertentu (Shihab, 1994:398).

\section{Dakwah yang Beretika}

Dewasa ini Kementerian Agama mempunyai tiga peran strategis yaitu peningkatan pemahaman dan pengamalan agama, pembinaan kerukunan antar umat beragama, serta mengawal akhlak dan moral bangsa.

Kehadiran SKB tentang tata cara pendirian rumah ibadah (SKB No. 1 Tahun 1969 yang akhirnya diperbaharui dengan SKB Menteri Dalam Negeri (Mendagri) dan Menteri Agama (Menag) RI No 8 TAHUN 2006 dan No 9 Tahun 2006), juga SK Menteri Agama tentang Penyiaran Agama (SK Menag No. 70 tahun 1978), aplikasi UU Pendidikan Nasional yang mewajibkan anak didik menerima pelajaran agama sesuai yang dianutnya (UU No.2 tahun 1989) membawa angin segar terciptanya keharmonisan kerukunan umat beragama.

Pelaksanaan penyiaran agama tidak dibenarkan untuk ditujukan terhadap orang atau kelompok orang yang telah memeluk/menganut 
agama lain dengan cara menggunakan bujukan dengan atau tanpa pemberian barang dan lainnya dengan tujuan mengajak pindah agama atau menyebarkan pamflet, majalah, buku-buku dan lainnya kepada mereka yang sudah beragama (SKB Menag-Mendagri No. 1/197 pasal 4)

Etika berdakwah dalam konteks menghargai dan menghormati hak asasi individu untuk beragama atau berkepercayaan merupakan keniscayaan yang tidak dapat ditawar-tawar lagi. Berikut ini beberapa diktum mengenai etika dakwah dalam perspektif quranik.

\section{Dakwah adalah mengajak}

Dakwah tampil sebagai aktivitas yang membebaskan, meneguhan spiritual, dan menjadi penawar kegundahan batin manusia. Pertama, dakwah adalah menyampaikan. Tugas seorang juru dakwah adalah menyampaikan QS. Yasin (36): 17 dan memehami bahwa dakwah sangat erat hubungannya dengan hidayah. Kedua, dakwah bukan memaksa dan menguasai. Islam melarang memaksa mereka untuk memasuku agama Islam. Ayat Al-Qur'an yang melarang paksaan dalam menganut agama itu adalah turun sebelum Surat Al-Bar'aah (At-Taubat), di mana disyari'atkan memungut pajak (jizyah). Maka paksaan dalam menganut agama itu adalah terlarang secara mutlak (Abduh 1991:16). Ketiga, dakwah bukan mencela agama lain. Kegiatan dakwah atau misi tidak boleh dipenuhi dengan sindiran, sarkasme, cacian dan makian atas umat lain agama atau agama orang lain itu sendir dan tidak menyerupai penyebaran kebencian yang mengumbar umpatan dan olok-olok atas pihak luar. Keempat, berdakwah dengan visi dan misi dan yang jelas. Dakwah mempersuasi manusia kepada al-khayr, mewujudkan al-Ma'ruf, dan mencegaah kemungkaran agar tercipta masyarakat yang muflihun penuh dengna al-Falah dalam kehidupan dunia dan akhirat.

\section{Simpulan}


Kehirukpikukan aktivitas dakwah di era modern dan majemuk ini tidak terhindarkan jika ketertiban dan kedamaian tidak diharmoniskan. Dalam ketertiban ada pengekangan dan kendali dan dalam kedamaian ada kebebasan. Islam, Kristen, dan Budha sebagai agama misi yang mewajibkan pemeluknya untuk menyebarluaskan ajaran-ajarannya sesungguhnya telah memliki aturan main, etika, dan kebiasaan luhur dalam berdakwah. Tugas para da'i adalah memahami ajaran agama dengan berbagai macam pendekatan teologis normatif, antropolgis, sosiologis, filosofis, historis, budaya, dan psikologis agar memahami agama melalui naqli, aqli, nan kasyf secara serentak dan tidak secara parsial.

\section{Daftar Pustaka}

Al-Maraghi, Musthofa. 1993.Tafsir al-Maraghi. Alih Bahasa Bahrun Abu Bakar. Semarang:Toha Putra.

Al-Tharabilisiy, Sayyid Husein Afandiy Al-Jisr. 1996. Memperkokoh Akidah Islamiyah. Bandung: al-Ma'arif

Al-Thobathoba'i, Muhammad Husein. 1991. Tafsir al Mizan. Beirut Libanon: al-Alami

Ali, Atabik. 1996. Kamus Kontemporer Arab-Indonesia. Yogyakarta: Yayasan Ali Maksum Pondok Pesantren Krapyak

Ali, Mukti.1996. Memahami Beberapa Aspek Ajaran Islam. Bandung: Mizan. Al-Qahthani, Muhammad bin Sa'id. 2000. Loyalitas dan Antiloyalitas dalam Islam. Alih Bahasa Salafudin Abu Sayid. Solo: Era Intermedia Amin, Masyhur. 1997. Dakwah Islam dan Pesan Moral. Edisi Juni. Yogyakarta: Al-Amin

Andito.1998. Atas nama agama wacana dalam dialog bebas konfik. Bandung: Pustaka Hidayah

Azra, Azyumardi. 1996. Pergolakan politik Islam dari fundamentalisme hingga post modernisme. Jakarta: Paramadina 
Baidlawi, Zakiyudin. 2005. Kredo Kebebasan Agama. Jakarta: PSAP BAPEDA. 2008. Salatiga dalam Angka. Salatiga: BAPEDA

Basyuni, Maftuh. 2006. Kebijakan dan Strategi Kerukunan Umat Beragama. Jakarta: Depag

Budihardjo. 2007. Dakwah dan Pengentasan Kemiskinan. Yogyakarta: Sumbangsih Pemikiran

Dewan Dakwah Islamiyah. 1990. Kristenisasi di Indonesia. Jakarta: Media Dakwah

Hanis, Muafi. 2007. Manajemen Dakwah, Dakwah dengan Tulisan Sebuah Peluang. Yogyakarta: Panji Pustaka

Husain, Adian. 2002. Penyesatan Opini Sebuah Rekayasa Mengubah Citra. Jakarta: Gema Insani Press.

Katsir, Imadudin abil Fida Isma'il .tt. Tafsir al-Qur'anil Adzim. Semarang: Toha Putra

Nata, Abudin. 2013. Metodologi Studi Islam. Jakarta: Raja Grafindo Persada.

Nugroho, Singgih. 2008. Menyitas dan Menyebrang Perpindahan Missal

Keagamaan Pasca 1965 di Pedesaaan Jawa. Yogyakarta: Syarikat

Puslitbang Kehidupan Keagamaan. 2007. Kompilasi Peraturan Perundang-

Undangan Kerukunan Hidup Umat Beragama. Jakarta: Depag

Shihab, Quraish. 1999. Wawasan Al Qur'an. Bandung: Mizan. . 2000. Tafsir Al-Mishbah. Jakarta: Lentera Hati. 1992. Membumikan al Qur'an. Bandung: Mizan.

Soekanto, Soerjono. 1993. Faktor-faktor yang Mempengaruhi Penegakan Hukum. Jakarta: Raja Grafindo

Takariawan, Cahyadi. 2005. Prinsip-Prinsip Dakwah. Yogyakarta: Izzah Pustaka

Warson, Ahmad. 1998. Kamus al-Munawir. Yogyakarta: Yayasan Ali Maksum Pondok Pesantren Krapyak

Yani, Ahmad. 2005. Bekal Menjadi Khotib dan Mubalig. Jakarta: Gema Insani Press 